Article

\title{
Impact of Food Sustainability Labels on the Perceived Product Value and Price Expectations of Urban Consumers
}

\author{
Joanna Kaczorowska *®i), Krystyna Rejman ${ }^{\circledR}$, Ewa Halicka, Agata Szczebyło \\ and Hanna Górska-Warsewicz \\ Department of Food Market and Consumer Research, Institute of Human Nutrition Sciences, Warsaw University \\ of Life Sciences WULS-SGGW, 02-776 Warsaw, Poland; krystyna_rejman@sggw.pl (K.R.); \\ ewa_halicka@sggw.pl (E.H.); agata_szczebylo@sggw.pl (A.S.); hanna_gorska_warsewicz@sggw.pl (H.G.-W.) \\ * Correspondence: joanna_kaczorowska@sggw.pl
}

Received: 26 November 2019; Accepted: 14 December 2019; Published: 17 December 2019

\begin{abstract}
Sustainable labelling is an important tool in raising awareness and informing potential buyers regarding environmental, economic and social issues. This study provides insights into consumers' value of food sustainability labels through the exploration of the impact of logos on their purchasing decisions (willingness to buy (WTB)) and readiness to pay (willingness to pay (WTP)) a higher price for sustainability-labelled products. Data was collected via an online survey among a sample of 423 adult city dwellers in Poland. The structured questionnaire beside sections concerning consumer buying behaviour and perception of the food labels consisted of a behavioural choice experiment (CE), where two categories of plant products: fresh (apples or bananas) and non-perishable (rice or beans) varied by type of labelling (logos: Euro-leaf, PGI, Fair Trade or without logo) and by price. Cluster analysis revealed two consumer groups (named "Sceptical" and "Mindful") that had varied opinions and perceptions of sustainable labelled food and buying behaviour. The research results indicate that when the logo is poorly-known even consumers with positive attitudes towards sustainability do not use it as a cue when shopping for food. Moreover, urban consumers were very price sensitive and showed a restrained desire to pay a higher price for sustainability labelled products.
\end{abstract}

Keywords: sustainability labels; willingness to buy; willingness to pay; food choice; urban consumers; Poland

\section{Introduction}

Sustainable food consumption is an important aspect of sustainable development and is becoming more urgent with every passing year [1]. It requires changes in everyday eating patterns, particularly a switch from animal to a plant-based diet; reducing food waste at home as well as purchasing seasonal, local and sustainability-labelled products (also known as eco-labelled, environmental-labelled or certified for sustainability) [2,3]. In the European context sustainable food labelling is a tool originated from the need to raise consumer awareness with the aim of altering consumption patterns to benefit the environment and ensure positive economic, society and health outcomes $[4,5]$.

Sustainability labelling of food products is voluntary and can be managed by private or public economic entities (such as groups of producers, retailers, NGOs, public authorities and policy makers), to provide information to consumers about certain aspects of the food they buy or its production method [6]. Due to the way it operates in the food chain and the extent to which end-users are involved in communicating with the entity, sustainable labels are classified as B2C type (from Business-to-Consumer 
or from Business-to-Customer) $[7,8]$. They are often in the form of a logo and/or a statement on the product that tells the consumer that the food meets the standard of that scheme, e.g., the food is produced in a certain geographic region, is organically produced, is produced with respect to the local economy (e.g., prevents poverty) or in accordance to additional requirements relating to animal welfare [6]. Over the last few decades such labels have become an important market-oriented instrument in European Union policy for a healthy diet and environment $[9,10]$. It reduces the presence of asymmetric information, supports creating market transparency and allows consumers to feel confident about their everyday food choices [6]. Promoting food products by adding such a label has also become a popular marketing strategy that benefits small producers in overcoming a significant financial hurdle and assists private and public manufactures as well as retailers by ensuring a consistent supply that can meet a growing demand [11]. An inventory compiled for the European Commission in 2009 lists 441 different schemes for agricultural products and foodstuffs marketed in the EU Member States (in that number were 17 non-EU schemes), most of which were established during the first decade of the new century [12]. In 2013, the Ipsos, London Economics Consortium report indicated more than 900 food labelling systems operating in the EU Member States, Iceland and Norway [6]. Among them numerous schemes regarded sustainability issues. The European Commission survey in 2012 identified 129 different sustainability label-related food standards [13]. The Ecolabel Index (2016) indicated that there were 148 public and private sustainability standards and quality assurance schemes for food and beverages available at the EU or national levels what points to a gradual increase in their number $[10,14]$.

On the other hand, consumers have limited awareness of sustainability labels. Logos and statements are not always fully understood, credibility of the labels is unclear or there are doubts which authority is responsible for the certification. Consumers may also face difficulties in distinguishing them what together results in consumer confusion, reluctance and scepticism $[6,13,15]$.

Moreover, several studies have reported a conflict between the concern for environmental protection and the desire to buy and pay a higher price for sustainability labelled products. Sustainable food products are more expensive because of their production processes, which are costlier, from raw materials to certifications $[11,13,16]$. It is estimated that food systems are responsible for a number of environmental problems (anthropogenic greenhouse gas emissions, soil erosion and salinity, reduction of water quality, resource depletion etc.), social and economic costs (for instance decline in the size and vitality of rural communities, unjust labour practices leading to difficulties to financially survive), public health issues such as growth of overweight and obesity ratios, increasing mortality and morbidity levels caused by diet-related diseases and barriers to access healthy food [17]. However, some consumers expect sustainable products to use less resources (water, energy, and so on) and this causes a misunderstanding why this does not cut down the production costs and price. In parallel with this the difference between relatively cheap conventional items and more expensive sustainable food products is apparently too large for many consumers, to act upon their good intentions $[15,18]$. Therefore, premium prices for products that meet the sustainable consumption standards seems to be a significant barrier to desirable purchasing behaviour [19-21].

Price is a key extrinsic factor that affects purchase intention [21-23]. According to the neoclassical theory, consumers try to optimise their purchase decisions in order to satisfy their own needs as fully as possible. In this sense, when they accept a higher price for a product and buy it, they also reveal a higher preference for it $[19,24]$. Several studies have found positive willingness to pay (WTP) for sustainability-labelled food items $[5,11,20,25,26]$. Therefore, sustainability labelling might play a role in gaining added value of food products and influence the relative importance of their price. In this regard the aim of this study was to explore the impact of food sustainability labels on product value and price expectation with the following specific objectives:

- $\quad$ segmentation of consumers according to the sustainability labels perception;

- defining to what extent sustainability labels influence consumer buying behaviour (willingness to buy-WTB); 
- examining whether sustainability labels influence consumer preferences (willingness to pay-WTP).

\section{Materials and Methods}

\subsection{Selection of Food Products and Certification Schemes}

Two categories of certified food products of plant origin were used as a research objects: fresh products (apples and bananas) and non-perishable foods (rice and beans). The choice of food items was based on the assumption that plant food use resources less intensively and have a lower impact on the environment (compared to animal production) and therefore labelled plant products encourage more sustainable dietary choices. Products in each category were labelled with sustainability logos: EU organic farming or Protected Geographical Indication or Fair Trade as well as they appeared without any of them (Table 1).

Table 1. Categories of plant foods and sustainability logos selected for the study (in brackets the number of product presentations to customers).

\begin{tabular}{lll}
\hline \multirow{2}{*}{ TYPE OF CERTIFICATION } & \multicolumn{2}{c}{ PLANT FOODS } \\
\cline { 2 - 3 } & \multicolumn{1}{c}{ FRESH } & \multicolumn{1}{c}{ NON-PERISHABLE } \\
\hline EU organic farming (Euro-leaf) & $\begin{array}{l}\text { apples (315) } \\
\text { bananas (315) }\end{array}$ & $\begin{array}{l}\text { rice (317) } \\
\text { beans (317) }\end{array}$ \\
\hline Protected Geographical Indication (PGI) & apples “Grójeckie” (315) & beans “Korczyńska” (317) \\
\hline Fair Trade & bananas (315) & rice (317) \\
\hline No sustainability logo & $\begin{array}{l}\text { apples (315) } \\
\text { bananas (315) }\end{array}$ & $\begin{array}{l}\text { rice (317) } \\
\text { beans (317) }\end{array}$ \\
\hline
\end{tabular}

The selection of logos reflected the three main pillars of sustainable consumption concerns:

- $\quad$ ecology/environment: EU organic farming logo (Euro-leaf), that confirms that the product was produced, processed, transported and stored in accordance with EU organic farming rules, which are designed to promote environment protection, maintain the biodiversity and build consumer trust in organic products;

- economy: Protected Geographical Indication (PGI), which indicates the support for regional producers and local communities; the label can be placed on products of a particular quality, reputation or other characteristic resulting from the specific geographic region of production; buying such products contributes to the sustainable development of the regions;

- society: Fair Trade, which indicates an economic system created for farmers and manufacturers from developing countries to ensure their worthy functioning and community development; this certificate scheme promotes social and economic justice as well as crop cultivation with respect for the environment.

\subsection{Sampling Design}

Primary data were collected in 2016 using structured questionnaires that were distributed via computer-assisted web interviewing (CAWI). Respondents were selected among adults aged 19-65 living in seven big cities (over 50,000 inhabitants) of the Mazovia region located in central Poland (Mazowieckie voivodship). Mazovia is the best developed region in the country in terms of gross domestic product and growth, unemployment rate, personal income and education level. In this region are four cities with 50,000 to 100,000 people; two cities with 100,000 to 500,000 people; and Warsaw, the capital and the largest city in the country, with 1.7 million inhabitants. 
The sample choice was based on the assumption that residents of big cities tend to have better education, higher incomes and better access to products' offer and therefore may be more aware of sustainability issues and more familiar with sustainable food labelling $[3,6]$.

The quota sampling selection method according to the size of cities' population was used. Therefore, the sample consisted of 423 people where 250 CAWI were completed by residents of Warsaw, by far the biggest city in the region. The remaining questionnaires were filled out by inhabitants of the other six Mazovian cities with more than 50,000 inhabitants (Ostrołęka, Legionowo, Pruszków, Siedlce, Płock and Radom).

Additionally, an equal share of consumers from three age groups (19-34, 35-50, 51-65) was applied during the sample selection. Recruitment and data collection via an internet panel were conducted by a commercial market research agency ARC Rynek i Opinia. The study was carried out in accordance with guidelines laid down in the Declaration of Helsinki as well as the rules of ICC/ESOMAR International Code on Market, Opinion and Social Research and Data Analytic.

Two criteria for the participation in the study were established:

- $\quad$ personally making decisions to purchase at least half of the food products for the household;

- regular shopping of at least three products out of four: apples, bananas, rice and beans.

\subsection{Sample Characteristics}

In the sample, the proportion of women was slightly higher $(60 \%)$, which reflects the fact that in Poland usually women buy groceries for their households. The sample matched the proportions of age cohorts (19-34 years-33.6\%, 35-50 years-33.8\%, 51-65 years-32.6\%), and met the requirements concerning consumption habits (the share of frequent buyers of apples was $99.2 \%$, bananas $99.2 \%$, rice $99.3 \%$ and beans $82.3 \%$ ). Most of the respondents had higher education (17.5\% bachelor's degree, $47.5 \%$ master's or higher diploma), one-third had secondary and post-secondary education ( $22.0 \%$ and $9.7 \%)$, whereas only $2.8 \%$ of individuals revealed vocational education or lower, and 2 persons $(0.5 \%)$ refused to answer. The average size of the respondents' households was 2.76 (SD 1.09) persons, and 41.5\% had children below 16 years of age. A vast majority (81.8\%) of participants and their families did not follow special dietary recommendations due to food allergies and intolerances, vegetarian or other diets. In total, $31.2 \%$ of the respondents declared that their monthly net income per person in the household was above 2500 PLN (ca. 600 EUR), while only 7.6\% declared it below 1000 PLN (250 EUR). It is worth pointing out that average monthly available income per capita in the household in the Mazovia voivodship was 1781 PLN (ca. 427 EUR) in 2016 [27]. Slightly more than one-third of the sample (35.7\%) was satisfied with their economic situation (sufficient for satisfying all or almost all needs), more than half of the group (54.1\%) perceived it as sufficient (satisfying some needs) and $7.8 \%$ evaluated it as insufficient. $2.4 \%$ of respondents refused to answer.

\subsection{Measures}

Data was gathered using a questionnaire that consists of four sections: 1-buying behaviour, 2-behavioural choice experiment, 3-perceived value of labelled products; 4-participants' socio-demographic characteristics (Table 2). Before the survey, the questionnaire was validated on a pilot subset of 20 consumers.

The first section of the questionnaire involved 7 statements originated from the FRL (Food Related Lifestyles) tool, which is widely used in consumer studies $[28,29]$. The aim of this part was to recognize types of buying behaviour among respondents. All items were rated on a five-point scale (with $1=$ "not at all" and $5=$ "very much"). 
Table 2. Questionnaire structure.

\begin{tabular}{|c|c|}
\hline Section & Description \\
\hline 1. Buying behaviour & $\begin{array}{l}7 \text { statements originated from the FRL (Food Related Lifestyles): } \\
\text { 1. Product information is of high importance to me. I need to know } \\
\text { the list of ingredients (Importance of product information) } \\
\text { 2. I compare labels to choose the most nutritious food (Importance } \\
\text { of product information) } \\
\text { 3. I always check prices, even if I make small purchases } \\
\text { (Price criterion) } \\
\text { 4. For large food purchases I always go with a list of products I have } \\
\text { to buy (Shopping list) } \\
\text { 5. I don't see the reason to buy in specialized grocery stores, } \\
\text { e.g., traditional, local, organic, etc. (Novelty) } \\
\text { 6. I buy new products to test them (Novelty) } \\
\text { 7. I just love shopping for food (Joy of shopping) }\end{array}$ \\
\hline 2. Behavioural choice experiment (CE) & $\begin{array}{l}\text { "Please simply select the option you would be more likely to } \\
\text { purchase if you were actually shopping for } \\
\text { apples/bananas/rice/beans." }\end{array}$ \\
\hline Familiarity with different sustainability labels & $\begin{array}{l}\text { "Have you seen the following type of logos or statements on food } \\
\text { products ever before?" Please select one answer (Yes/No) for each } \\
\text { type of logo or statement. }\end{array}$ \\
\hline $\begin{array}{l}\text { 3. Perceived value of labelled products } \\
\text { "Sustainability labelled food products ..." }\end{array}$ & $\begin{array}{l}\text { 10 statements concerning opinions on sustainability- } \\
\text { labelled food: } \\
\text { 1. have a better taste or flavour } \\
\text { 2. have better nutritional composition } \\
\text { 3. contain more beneficial nutrients } \\
\text { 4. are obtained in an ethical way } \\
\text { 5. are safer for health } \\
\text { 6. contain less artificial ingredients (e.g., preservatives. colorants) } \\
\text { 7. are more natural (ingredients are only minimally processed) } \\
\text { 8. have generally better quality } \\
\text { 9. are fresh } \\
\text { 10. are easily available }\end{array}$ \\
\hline
\end{tabular}

\begin{tabular}{|c|c|}
\hline “Sustainability labels on food products ... " & $\begin{array}{l}8 \text { statements concerning usefulness of labels: } \\
\text { 1. make shopping difficult, as it is another piece of information on } \\
\text { the packaging } \\
\text { 2. make purchases more difficult-there are too many } \\
\text { front-of-pack logos } \\
\text { 3. are difficult to distinguish-they are similar to each other } \\
\text { 4. are not visible on product packaging } \\
\text { 5. are only marketing tricks } \\
\text { 6. are the reason for demanding an excessive price } \\
\text { 7. are not reliable because certification processes raise my doubts } \\
\text { 8. are not very convincing-I have too little knowledge about them }\end{array}$ \\
\hline "A producer of sustainability labelled products ... " & $\begin{array}{l}6 \text { statements concerning producers of certified for } \\
\text { sustainability products: } \\
\text { 1. inspire greater trust } \\
\text { 2. takes care of consumers' welfare } \\
\text { 3. cares about the company's image } \\
\text { 4. takes care of its finances } \\
\text { 5. is a resourceful entrepreneur } \\
\text { 6. has generally better reputation }\end{array}$ \\
\hline 4. Socio-demographic characteristics & $\begin{array}{l}7 \text { factors: gender, age, education level, family size and composition, } \\
\text { following special dietary rules, income, and self-assessment of the } \\
\text { household income situation }\end{array}$ \\
\hline
\end{tabular}

In the second section of the CAWI a behavioural choice experiment (CE) method was used to understand the consumers' value attached to the products with (and without) sustainability labels and willingness-to-buy (WTB) and willingness-to- pay (WTP) for them. WTB and WTP issues are widely described in scientific literature [24]. CE methods are based on Random Utility Theory postulating that an individual who makes a choice among different alternatives strives to maximize utility and because of that are accurate in imitating a real-buying situation [30]. Participants in our research were involved in a virtual online grocery shopping exercise. To avoid boredom, consumers made virtual 
purchases of three out of four plant products according to the scheme Balanced Incomplete Block Design (BIBD) [31].

The products were presented sequentially by category: fresh (apples or bananas), non-perishable (rice or beans) and varied by type of labelling (Euro-leaf, PGI, Fair Trade or without logo) and by price. Items in particular categories were shown to the respondents on one screen in random order to avoid the error of the first impression. Depending of real market offer two products were labelled with sustainability certificate logos and the additional one always appeared without a logo. For example, in the case of bananas, two of them were labelled with the sustainability logo: Euro-leaf or Fair Trade and the third appeared without any certificate.

At the beginning of the experiment, the same base price (adequate to real market values in PLN: apples 2.5 per $1 \mathrm{~kg}$, bananas 3.99 per $1 \mathrm{~kg}$, beans 4.85-packaging $0.5 \mathrm{~kg}$, rice 3.99—packaging $0.5 \mathrm{~kg}$ ) was shown for each product. Participants were asked to choose the product they would buy while shopping in a store (measurement of WTB). If the respondent chose a labelled product, then in the next choice the price of this item increased by $10 \%$. Then the respondent could maintain the choice of the previously selected product at a higher price or choose another (with or without a different sustainability label), which was kept at lower level (WTP measurement). The price increase was carried out until the respondent changed his or her preferences and chose the product without a logo.

Respondents were asked about their familiarity with EU organic farming, Protected Geographical Indication and Fairtrade logos. The responses were measured on a dichotomous scale. This was studied after the choice experiment in order not to influence the decisions of respondents.

Perceived value of the products with sustainability labels (third section of the questionnaire) was measured with the use of 10 statements related to the quality of sustainability labelled foods in comparison to conventional products (without logos), 8 statements on the usefulness of these labels and 6 statements regarding the respondents' opinion about producers of sustainability labelled food products. Participants indicated their response on a five-point Likert scale.

The final part of the questionnaire contained questions on socio-demographic characteristics of respondents: gender, age, education level, family size and composition, following special dietary rules, income and self-assessment of the household income situation.

\subsection{Statistical Analyses}

Data were analysed using the statistical software package IBM SPSS Statistics version 25 . The first step was focused on identifying consumer segments using buying behaviour and perception of the food labels as profiling variables. To reduce the number of variables and indicate the relationships between them Factor Analysis was performed through PCA (Principal Component Analysis) method and followed by a Varimax rotation with Kaiser normalization [32]. In order to conduct factor extraction, the criterion eigenvalue greater than one was chosen and confirmed by the Scree Plot. As a result, five components explaining $60.789 \%$ of the original variance were identified. The reliability of the variables was measured through the Cronbach's alpha.

To determine which variables are the most important in the components, the weight for individual items were compiled and sorted. In the whole model only one item "I don't see the reason to buy in specialized grocery stores, e.g., traditional, local, organic, etc." did not make a significant contribution to the model and was removed. Other variables loaded highly onto the extracted components (Table 3). 
Table 3. Component Matrix (PCA, Varimax Rotation Method-Kaiser Normalization).

\begin{tabular}{|c|c|c|c|c|c|c|}
\hline & & \multicolumn{5}{|c|}{ Component $\left(\%\right.$ of Variance $\left.{ }^{* *}\right) /$ Cronbach's Alpha Coefficient } \\
\hline & & $\begin{array}{c}\text { 1st (22.604) } \\
\alpha=0.939\end{array}$ & $\begin{array}{c}\text { 2nd (14.579) } \\
\alpha=0.872\end{array}$ & $\begin{array}{c}\text { 3rd (9.888) } \\
\alpha=0.789\end{array}$ & $\begin{array}{l}\text { 4th (9.197) } \\
\alpha=0.829\end{array}$ & 5 th $(4.521) *$ \\
\hline \multirow{9}{*}{$\begin{array}{l}\text { OPINIONS } \\
\text { "Sustainability } \\
\text { labelled food } \\
\text { products..." }\end{array}$} & have generally better quality & 0.853 & -0.096 & 0.102 & 0.121 & -0.043 \\
\hline & have better nutritional composition & 0.842 & -0.043 & 0.114 & 0.035 & 0.105 \\
\hline & $\begin{array}{l}\text { are more natural (ingredients are } \\
\text { only minimally processed) }\end{array}$ & 0.839 & -0.008 & 0.077 & 0.153 & -0.043 \\
\hline & are safer for health & 0.834 & -0.072 & 0.117 & 0.182 & -0.112 \\
\hline & contain more beneficial nutrients & 0.812 & -0.020 & 0.078 & 0.037 & 0.114 \\
\hline & $\begin{array}{l}\text { contain less artificial ingredients } \\
\text { (e.g., preservatives, colorants) }\end{array}$ & 0.802 & -0.049 & 0.099 & 0.137 & -0.163 \\
\hline & have a better taste or flavour & 0.756 & -0.046 & 0.012 & 0.096 & 0.336 \\
\hline & are obtained in an ethical way & 0.731 & -0.012 & 0.099 & 0.170 & 0.015 \\
\hline & are fresh & 0.704 & -0.073 & 0.045 & 0.103 & 0.405 \\
\hline \multirow{8}{*}{$\begin{array}{l}\text { USEFULNESS } \\
\text { "Sustainability } \\
\text { labels on food } \\
\text { products..." }\end{array}$} & $\begin{array}{l}\text { make purchase more difficult-there } \\
\text { are too many front-of-pack logos }\end{array}$ & -0.021 & 0.774 & -0.068 & -0.112 & 0.181 \\
\hline & $\begin{array}{l}\text { are not reliable because certification } \\
\text { processes raise my doubts }\end{array}$ & -0.263 & 0.771 & 0.069 & -0.035 & 0.070 \\
\hline & $\begin{array}{l}\text { are difficult to distinguish-they are } \\
\text { similar to each other }\end{array}$ & -0.009 & 0.768 & -0.070 & 0.058 & -0.199 \\
\hline & are only marketing tricks & -0.277 & 0.760 & 0.035 & -0.032 & 0.088 \\
\hline & $\begin{array}{l}\text { make shopping difficult, as it is } \\
\text { another piece of information } \\
\text { on the packaging }\end{array}$ & -0.065 & 0.726 & -0.061 & -0.113 & 0.315 \\
\hline & $\begin{array}{l}\text { are not very convincing-I have too } \\
\text { little knowledge about them }\end{array}$ & 0.012 & 0.726 & -0.023 & 0.015 & -0.224 \\
\hline & $\begin{array}{l}\text { are the reason for demanding an } \\
\text { excessive price }\end{array}$ & -0.092 & 0.633 & 0.070 & 0.159 & -0.211 \\
\hline & are not visible on product packaging & 0.164 & 0.581 & -0.099 & 0.028 & 0.023 \\
\hline \multirow{6}{*}{$\begin{array}{l}\text { BUYING } \\
\text { BEHAVIOUR }\end{array}$} & $\begin{array}{l}\text { to me product information is of high } \\
\text { importance. I need to know the list } \\
\text { of ingredients }\end{array}$ & 0.138 & -0.063 & 0.803 & 0.087 & -0.130 \\
\hline & $\begin{array}{l}\text { I compare labels to choose the most } \\
\text { nutritious food }\end{array}$ & 0.196 & -0.082 & 0.783 & 0.042 & -0.075 \\
\hline & $\begin{array}{l}\text { I always check prices, even if I make } \\
\text { small purchases }\end{array}$ & 0.012 & 0.057 & 0.708 & 0.037 & 0.059 \\
\hline & I buy new products to test them & 0.092 & -0.058 & 0.695 & 0.095 & 0.060 \\
\hline & I just love shopping for food & 0.039 & -0.052 & 0.579 & 0.068 & 0.312 \\
\hline & $\begin{array}{l}\text { for large food purchases I always go } \\
\text { with a list of products I have to buy }\end{array}$ & 0.053 & 0.010 & 0.567 & -0.030 & -0.037 \\
\hline \multirow{6}{*}{$\begin{array}{l}\text { PERCEPTION } \\
\text { "A producer of } \\
\text { certified } \\
\text { sustainability } \\
\text { products..." }\end{array}$} & is a resourceful entrepreneur & 0.182 & -0.011 & 0.087 & 0.798 & 0.064 \\
\hline & cares about the company's image & 0.211 & 0.057 & 0.147 & 0.746 & -0.129 \\
\hline & takes care of its finances & -0.043 & 0.286 & 0.029 & 0.656 & 0.035 \\
\hline & has generally better reputation & 0.475 & -0.234 & 0.018 & 0.633 & 0.048 \\
\hline & inspires greater trust & 0.519 & -0.253 & 0.007 & 0.576 & -0.022 \\
\hline & takes care of consumers' welfare & 0.517 & -0.298 & -0.016 & 0.517 & 0.208 \\
\hline $\begin{array}{c}\text { OPINIONS } \\
\text { "Sustainability } \\
\text { labelled food }(\ldots) \text { ". }\end{array}$ & are easily available & 0.374 & -0.085 & -0.012 & 0.062 & 0.728 \\
\hline $\begin{array}{l}\text { BUYING } \\
\text { BEHAVIOUR }\end{array}$ & $\begin{array}{l}\text { I don't see the reason to buy in } \\
\text { specialized grocery stores, } \\
\text { e.g., < traditional, local, organic, etc. }\end{array}$ & -0.167 & 0.136 & 0.177 & -0.033 & 0.227 \\
\hline
\end{tabular}

* Cronbach's alpha coefficient was not calculated because there is only one item. ** Total variance explained.

Cluster Analysis (K-means method) for respondent segmentation was then carried out [32]. This allowed us to determine two clusters. A one way Analysis of Variance test (ANOVA) determined that all variables were statistically significant $(p$-value $<0.000000)$. The $\mathrm{F}$ value showed that the most important variables for discriminating the clusters belonged to the 5th (availability of sustainability labelled products, F value 317.1273), and 1st (opinions on sustainable labelled food, 
174.3704) component followed by 4 th (perception of producers of certified for sustainability products, 102.9654), 2nd (usefulness of labels, 56.0714) and 3rd (buying behaviour, 48.4830) components.

The second step of statistical analysis was focused on determining the value of sustainability labelled food products for all respondents and extracted clusters through assessing their intention to purchase a product (WTB) and willingness to pay a higher price (WTP). Willingness to pay for a particular good is the amount of money someone is willing to give up in order to own the product. In the context of this study the interest was not on how many respondents were willing to pay for apples, bananas, beans or rice, but how much more they would be willing to pay for the same product when it carried a sustainability label. For this purpose, descriptive statistics (frequency, means and cross-tabulations) were used. To calculate the main effects and assess the existence of the statistically significant differences across consumer segments the Pearson Chi-square independence test was applied where $p \leq 0.05$ was interpreted as statistically significant.

\section{Results}

\subsection{Description of Consumer Clusters}

The study revealed two types of consumers that varied with respect to their opinions and perception of sustainability labelled food as well as their buying behaviour (Table 4). While almost $2 / 3$ of consumers forming Cluster $1(63.4 \%$, ) clearly did not pay much attention to sustainability labels, respondents in Cluster 2 (36.6\%) expressed goodwill towards sustainable products, labels and producers. In accordance with this distribution the participants of Cluster 1 were named "Sceptical" and the participants of Cluster 2 were named "Mindful". Whereas socio-demographic data did not significantly influence cluster membership (Table 4), attitudes and purchasing behaviour helped to explain the differences between clusters.

Table 4. Cluster Analysis: socio-demographic data.

\begin{tabular}{|c|c|c|c|c|}
\hline Variable & & $\begin{array}{c}\text { Total } \\
\text { Sample }(\%) \\
n=423\end{array}$ & $\begin{array}{l}\text { Cluster } 1(\%) \\
\text { "Sceptical" } \\
n=268\end{array}$ & $\begin{array}{l}\text { Cluster } 2(\%) \\
\text { "Mindful" } \\
n=155\end{array}$ \\
\hline \multirow{2}{*}{ Gender } & Male & 39.7 & 42.2 & 35.5 \\
\hline & Female & 60.3 & 57.8 & 64.5 \\
\hline \multirow{3}{*}{ Age (years) } & $19-34$ & 33.6 & 33.6 & 33.5 \\
\hline & $35-50$ & 33.8 & 35.1 & 31.6 \\
\hline & $51-65$ & 32.6 & 31.3 & 34.8 \\
\hline \multirow{4}{*}{ Education } & Primary or vocational & 2.8 & 2.6 & 3.2 \\
\hline & Secondary & 31.7 & 32.5 & 30.3 \\
\hline & Higher & 65 & 64.5 & 65.8 \\
\hline & Refusal & 0.5 & 0.4 & 0.6 \\
\hline \multirow{4}{*}{$\begin{array}{l}\text { Household size } \\
\text { (number of people) }\end{array}$} & 1 & 12.3 & 11.9 & 12.9 \\
\hline & 2 & 32.9 & 34.7 & 29.7 \\
\hline & 3 & 27.7 & 27.2 & 28.4 \\
\hline & 4 and more & 27.2 & 26.1 & 29 \\
\hline \multirow{4}{*}{ Household's income } & Satisfying & 35.7 & 34.7 & 37.4 \\
\hline & Sufficient & 54.1 & 53.7 & 54.8 \\
\hline & Insufficient & 7.8 & 9.3 & 5.2 \\
\hline & Refusal & 2.4 & 2.2 & 0.6 \\
\hline
\end{tabular}

Cluster 1 "Sceptical" ( $\mathrm{n}=\mathbf{2 6 8})$ considered sustainability labelled products as relatively poorly available (mean 2.43 , where $1=$ strongly disagree, and $5=$ strongly agree) and expressed rather weak opinions about sustainable labelled food. They were unlikely to perceive products with sustainability $\log$ os as fresh or more tasty than other food products available on the market (mean 2.90 and 
2.94, respectively). Cluster 1 was not clearly convinced if certified products have better nutritional composition (mean 3.15) or whether they are more natural with minimally processed ingredients (mean 3.36). More than half of this segment (57.1\%) did not consider the production method of certified products as more ethical (mean 3.32). With reference to the assessment of usefulness of labels "Sceptical" consumers claimed that sustainability logos are the reason for demanding an excessive price for a product (mean 3.80 at reversed scale), but they also admitted that sustainability labels are not very convincing for them because of their too little knowledge about this (mean 3.54 at reversed scale). Respondents in Cluster 1 perceived producers who use certificates as resourceful entrepreneurs (mean 3.55), who care more about the company's image and their own finances (mean 3.87 and 3.78, respectively) than about the consumers' welfare (mean 3.16). Finally, buying behaviour significantly differed between respondents from both clusters. In general the "Sceptics" paid less attention to the labels when choosing food. They were more inclined to mark a neutral midpoint on the scale when asked about the importance of the information on the packaging and their willingness to check the list of ingredients (mean 3.76, 16.4\% of answers "I don't know") as well as about comparing the labels for choosing the most nutritious food (mean 3.51 and $28.7 \%$, respectively). They always check the prices of product, even if they make small purchases of food (mean 3.72). Consumers in Cluster 1 moderately enjoyed shopping for food (mean 3.26) and were moderately interested in trying new food products (mean 3.53). Almost one quarter of them (23.9\%), didn't make lists of products they have to buy for large food purchases (mean 3.51).

Cluster 2 "Mindful" $(n=155)$ perceived sustainability labelled products better than foods without this type of logo. Most of the participants were convinced that sustainability labelled products are fresher (mean 3.88, 69\% of answers "I agree" and "I strongly agree") and had a better nutritional composition (mean 4.06 and $86.5 \%$ of positive responses). "Mindful" respondents considered such products to be better in quality (mean 4.14 ) and tastier (mean 3.75). A vast majority of them $(81.3 \%)$ were aware about ethical way of their production (mean 4.03). It is worth noting that the "Mindful" group also declared easier availability of labelled products (mean 3.65) than consumers from the first segment (mean 2.43). In general respondents in Custer 2 had no doubt about the usefulness of sustainability labels. A significant share of them (63.2\%) disagreed that sustainability labels make shopping difficult, as it is another piece of information on the packaging (mean 2.41 at reversed scale). "Mindful" consumers tend to perceive products with sustainability labels to be reliable (mean 2.67 at reversed scale) rather than being just a marketing trick (mean 2.77 at reversed scale). Consistently Cluster 2 better (than respondents in Cluster 1) perceived producers of sustainability labelled food. They saw them as taking care of the company's image (mean 4.25) as well as consumer benefits (mean 3.97). In the opinion of "Mindful" respondents such producers enjoy a better reputation (mean 4.13) and inspire greater trust (mean 4.14). When analysing buying behaviour, higher involvement in food purchases might be observed in Cluster 2 (mean 4.05). The vast majority of its members (89\%) admitted that information on the packaging is of high importance because of the possibility to check the list of ingredients and compare labels in order to choose the most nutritious food (mean 4.28 and 4.16, respectively). There is a higher prevalence of individuals declaring the joy of shopping food (mean 3.80) and the willingness to try new products (mean 3.99).

\subsection{Familiarity of Sustainability Labels}

Before the choice experiment, we checked the knowledge of the logos that we used in it: Euro leaf, PGI and Fair Trade.

The results (Table 5) indicate that the majority $(70.9 \%)$ of study participants knew at least one of the presented logos. Familiarity of one label was declared by $40.4 \%$ of the sample, every fourth respondent $(25.3 \%)$ admitted knowing two, whereas only $5.2 \%$ of participants declared familiarity with all three presented sustainability labels. The analysis of familiarity with sustainability labels by type reveal that the most recognized label was EU organic farming (48.9\%), followed by Fair Trade (30.7\%) and Protected Geographical Indication (27.0\%). These findings differ slightly from the results of the 
DG Agri survey conducted in 2017 on a representative sample of EU28 population [33]. Fair Trade logo had the highest recognition (EU28 average 37\%, but average among the Polish population was 9\%), followed by EU organic farming (EU28 27\%, PL 29\%) and the Protected Geographical Indication (EU28 18\%, PL 15\%). The variation in level of familiarity can be explained by the differences in socio-demographic characteristics of the studied samples.

Table 5. Familiarity with sustainability labels and willingness to buy plant food, by consumer group and label.

\begin{tabular}{|c|c|c|c|c|c|c|}
\hline \multirow{3}{*}{$\begin{array}{l}\text { Sustainability } \\
\text { Label }\end{array}$} & \multirow{3}{*}{$\begin{array}{c}\text { Familiarity } \\
(\%) *\end{array}$} & \multirow{3}{*}{$\begin{array}{l}\text { Consumer } \\
\text { Group }\end{array}$} & \multicolumn{4}{|c|}{ Product Category } \\
\hline & & & \multicolumn{2}{|c|}{ Fresh } & \multicolumn{2}{|c|}{ Non-Perishable } \\
\hline & & & APPLES (\%) & BANANAS (\%) & BEANS (\%) & RICE (\%) \\
\hline \multirow{3}{*}{$\begin{array}{l}\text { EU organic } \\
\text { farming } \\
\text { (Euro-leaf) }\end{array}$} & 48.9 & Total ** & 22.0 & 29.7 & 28.2 & 33.7 \\
\hline & 41.4 & Cluster 1 & 16.6 & 25.4 & 23.5 & 28.1 \\
\hline & 61.9 & Cluster 2 & 31.4 & 37.1 & 37.7 & 45.3 \\
\hline \multirow{3}{*}{$\begin{array}{l}\text { Protected } \\
\text { Geographical } \\
\text { Indication } \\
(\mathrm{PGI})\end{array}$} & 27.0 & Total ** & 30.1 & \multirow{3}{*}{ no market offer } & 39.6 & \multirow{3}{*}{ no market offer } \\
\hline & 23.9 & Cluster 1 & 29.3 & & 36.9 & \\
\hline & 32.3 & Cluster 2 & 31.4 & & 45.3 & \\
\hline \multirow{3}{*}{ Fair Trade } & 30.7 & Total ** & \multirow{3}{*}{ no market offer } & 26.6 & \multirow{3}{*}{ no market offer } & 29.7 \\
\hline & 26.5 & Cluster 1 & & 22.7 & & 27.6 \\
\hline & 38.1 & Cluster 2 & & 33.3 & & 34.0 \\
\hline \multirow{3}{*}{$\begin{array}{c}\text { No } \\
\text { sustainability } \\
\log \text { os }\end{array}$} & 29.1 & Total ** & 47.9 & 43.7 & 32.2 & 36.5 \\
\hline & 34.7 & Cluster 1 & 54.1 & 51.9 & 39.6 & 44.2 \\
\hline & 16.1 & Cluster 2 & 37.1 & 29.5 & 17.0 & 20.8 \\
\hline
\end{tabular}

${ }^{*}$ Respondent could declare familiarity of more than one logo. ${ }^{* *}$ Percent of all respondents who declared willingness to buy a particular product.

In examining the relationship between consumers' segments, it is worth mentioning that Cluster 2 ("Mindful" respondents) showed a higher familiarity of sustainability labels (83.9\%). A gap of 18.6 percentage points separated this group from the Cluster 1 ("Sceptical"). Differences can also be observed due to the knowledge of the number of given logos. More respondents from Cluster 2 declared their knowledge of one ( $47.7 \%$ vs. $43.7 \%$ of "Sceptical" consumers), two ( $23.9 \%$ vs. $16.8 \%$, respectively) and three symbols ( $12.3 \%$ and $4.9 \%)$.

In respect to the type of sustainability label, Euro-leaf logo has the highest recognition among respondents from both clusters (41.4\% in Cluster 1 and 61.9\% in Cluster 2). The second in this respect was the Fair Trade logo (26.5\% and 38.1\%, respectively). The consumers from both segments revealed the lowest familiarity with Protected Geographical Indication label (23.9\% and $32.3 \%$, respectively).

\subsection{Impact of Logos on Purchasing Decisions}

To examine the extent to which consumers take sustainability labels into account when buying food, participants were asked at the beginning of a behavioural experiment to choose one product in particular category offered to them. Choices varied whether or not the product carried a sustainability logo. The choice did not vary according to price and therefore the observations allowed us to estimate how the type of label affects the consumer's intention to purchase different categories of products.

Just over a half of the respondents wanted to buy products that carry sustainability logos. In general, Cluster 2 ("Mindful") decided to buy them more often than members of the "Sceptical" group (p-value for apples 0.005 , for bananas 0.001 , and for beans and rice 0.000 ).

Additionally, the "Mindful" respondents tended to choose labelled products more frequently than analogical conventional items (without logo). Again, the analysis revealed statistical difference in WTB for beans $(p=0.000)$, rice $(p=0.000)$, bananas $(p=0.000)$ and apples $(p=0.005)$.

The analysis of sustainability label choices by type of products (Table 5) shows that the PGI logo had the most significant impact on respondent's willingness to buy. The largest share of the 
study participants (ca. one third of them) chose products with this logo in all product categories, excluding bananas and rice where PGI label were not shown. While examining the proportion of respondents by clusters, Cluster 1 ("Sceptical") showed the highest interest in PGI labelled products ( $29.3 \%$ of respondents), while sustainability label choices of Cluster 2 were mixed. The "Mindful" group indicated WTB items that was marked with PGI or Euro-leaf logo. In the case of apples in both types of logo the share of respondents was equal to $31.4 \%$. Beans with the organic farming logo (Euro-leaf) received $37.7 \%$ of declarations and PDI beans $45.3 \%$, so the differences in choices were in favour of the PGI.

Despite the declared familiarity with the Fair Trade logo (about one-third of all consumers), the products that had this certificate were no taken into account as first choice.

Finally, it is surprising that during the experiment, around a one third of the "Sceptical" group chose products with the PGI label (beans $36.9 \%$, apples $29.3 \%$ ) while only $23.9 \%$ of them declared familiarity with this certificate. This may suggest that these study participants recognized or perceived the logo as a certain guarantee or benefit, which positively affects their willingness to buy.

It is worth to emphasize also that in the case of apples and bananas the influence of certificates on product choice was not observed. More than half of the WTB declarations from Cluster 1 and about one third of Cluster 2 concerned products without certificates. In the of beans, PDI logo had the greatest impact, while the choice of rice was affected by the EU organic farming logo. Among "Mindful" respondents both products received $45.3 \%$ of declarations.

\subsection{Readiness to Pay a Higher Price}

The weighted average of willingness to pay for labelled products (an average acceptable price increase as a percentage of the base price) and the number of respondents declaring readiness to buy products while the price is increasing are summarized in Table 6.

Table 6. Average willingness to pay for sustainability-labelled products and the number of respondents declaring readiness to buy them.

\begin{tabular}{|c|c|c|c|c|c|}
\hline \multirow{2}{*}{ Logo/PRODUCT } & \multirow{2}{*}{$\begin{array}{l}\text { Average * } \\
\text { Willingness to Pay }\end{array}$} & \multirow{2}{*}{$\begin{array}{l}\text { Consumer } \\
\text { Group }\end{array}$} & \multicolumn{3}{|c|}{ PRICE } \\
\hline & & & Base (\% of Group) & $+10 \%$ & $+20 \%$ \\
\hline \multirow{3}{*}{$\begin{array}{l}\text { EU organic farming (Euro-leaf) } \\
\text { APPLES }\end{array}$} & \multirow{3}{*}{$16.2 \%$} & Total & 69 & $62(-11 \%)$ & $47(-32 \%)$ \\
\hline & & Cluster 1 & 44 & $39(-13 \%)$ & $28(-37 \%)$ \\
\hline & & Cluster 2 & 25 & $23(-9 \%)$ & $19(-25 \%)$ \\
\hline \multirow{3}{*}{$\begin{array}{l}\text { EU organic farming (Euro-leaf) } \\
\text { BANANAS }\end{array}$} & \multirow{3}{*}{$12.2 \%$} & Total & 94 & $66(-29 \%)$ & $35(-62 \%)$ \\
\hline & & Cluster 1 & 59 & $36(-39 \%)$ & $15(-75 \%)$ \\
\hline & & Cluster 2 & 34 & $29(-18 \%)$ & $20(-41 \%)$ \\
\hline \multirow{3}{*}{$\begin{array}{l}\text { EU organic farming (Euro-leaf) } \\
\text { BEANS }\end{array}$} & \multirow{3}{*}{$13.0 \%$} & Total & 89 & $84(-5 \%)$ & $42(-53 \%)$ \\
\hline & & Cluster 1 & 57 & $53(-6 \%)$ & $26(-55 \%)$ \\
\hline & & Cluster 2 & 33 & $31(-5 \%)$ & $16(-50 \%)$ \\
\hline \multirow{3}{*}{$\begin{array}{l}\text { EU organic farming (Euro-leaf) } \\
\text { RICE }\end{array}$} & \multirow{3}{*}{$11.0 \%$} & Total & 107 & $99(-7 \%)$ & $42(-61 \%)$ \\
\hline & & Cluster 1 & 68 & $64(-5 \%)$ & $24(-64 \%)$ \\
\hline & & Cluster 2 & 39 & $35(-10 \%)$ & $17(-56 \%)$ \\
\hline \multirow{3}{*}{$\begin{array}{c}\text { Protected Geographical Indication (PGI) } \\
\text { APPLES }\end{array}$} & \multirow{3}{*}{$16.3 \%$} & Total & 95 & $78(-17 \%)$ & $36(-62 \%)$ \\
\hline & & Cluster 1 & 60 & $45(-25 \%)$ & $16(-74 \%)$ \\
\hline & & Cluster 2 & 35 & $33(-6 \%)$ & $20(-42 \%)$ \\
\hline \multirow{3}{*}{$\begin{array}{c}\text { Protected Geographical Indication (PGI) } \\
\text { BEANS }\end{array}$} & \multirow{3}{*}{$17.3 \%$} & Total & 126 & $90(-28 \%)$ & $48(-62 \%)$ \\
\hline & & Cluster 1 & 80 & $56(-30 \%)$ & $26(-68 \%)$ \\
\hline & & Cluster 2 & 46 & $34(-25 \%)$ & $22(-52 \%)$ \\
\hline \multirow{3}{*}{$\begin{array}{l}\text { Fair Trade } \\
\text { BANANAS }\end{array}$} & \multirow{3}{*}{$11.4 \%$} & Total & 84 & $65(-22 \%)$ & $24(-71 \%)$ \\
\hline & & Cluster 1 & 53 & $37(-30 \%)$ & $13(-76 \%)$ \\
\hline & & Cluster 2 & 31 & $27(-11 \%)$ & $11(-63 \%)$ \\
\hline \multirow{3}{*}{$\begin{array}{l}\text { Fair Trade } \\
\text { RICE }\end{array}$} & \multirow{3}{*}{$14.3 \%$} & Total & 94 & $62(-35 \%)$ & $31(-67 \%)$ \\
\hline & & Cluster 1 & 60 & $29(-52 \%)$ & $13(-78 \%)$ \\
\hline & & Cluster 2 & 34 & $33(-8 \%)$ & $18(-47 \%)$ \\
\hline
\end{tabular}

\footnotetext{
* Percentage $\mathrm{f}$ base price. ${ }^{* * *}$ In brackets the percentage of respondents giving up their purchase.
} 
The analysis of average WTP showed that respondents were generally willing to pay the extra amount of money for a product with a sustainability label. Across all products and logos, the willingness to pay more for the same product when it had a sustainability label varied from $11 \%$ (organic rice) to $17 \%$ (PDO beans) of the base price. The highest WTP in relation to the base price was applied to products with a PGI logo (16.3\% for apples and $17.3 \%$ for beans), followed by EU organic farming (from $11.0 \%$ for rice to $16.2 \%$ for apples) and the Fair Trade (11.4\% for bananas and $14.3 \%$ for rice) certificates.

Comparing the readiness to buy products with sustainability labels at a higher price it can be observed that as the price increased, more people switched their choice. If the price rose by $10 \%$, about one-fifth of respondents changed their choice to a cheaper product with another label or without a sustainability label. With a $20 \%$ increase in price, more than half of respondents gave up their choice.

It should be noted that for Cluster 1 ("Sceptical") even a small increase in price resulted in significant share of respondents (ca. one quarter) selecting a cheaper option. As prices increased, Cluster 2 ("Mindful") remained loyal to its choices for a longer time. Statistical analysis confirmed significant differences $(p<0.001)$ between clusters in willingness to pay for all labelled products at $10 \%$ price increase level. However, with each subsequent price increase, fewer consumers expressed their willingness to pay for labelled products and differences between groups became less visible.

The analysis of the switching between products with different logos (as the price increased) is quite surprising. Consumers are more loyal when choosing Euro-leaf labelled products than with PGI logo although that sustainability label tend to influence consumers' preferences the most. The average percent of respondents giving up their purchase after the first increase in price was $13 \%$ as compared to $22 \%$ among those who choose PGI. At a $20 \%$ price increase however, this observation was repeated (Euro-leaf 51\% vs. PGI 60\%).

Fair Trade labelled products with each subsequent price increase noted the largest drops in willingness to pay ( $27 \%$ after the first and $67 \%$ after the second price increase). This means that the Fair Trade logo has the least impact on the buying behaviour of the surveyed group of Polish consumers.

\section{Discussion}

Consumers, particularly in wealthier societies, are confronted with complex food choices as a result of possible conflicting interests between individual objectives (direct benefits for the buyer) and long-term collective goals (benefit the environment/planet, positive economic, society and health outcomes in the future). In this regard, today's food consumption cannot be fully explained by socio-demographic factors (such as age and income), but there is a need for broader perspective [1,34-36]. As a consequence, in addition to socio-demographic characteristics many other variables (such as personality characteristics, values and lifestyles, actual behaviour) are used to identify homogenous consumer groups and effective communication strategies around sustainable food consumption $[9,37,38]$. In this study two consumer segments were identified ("Sceptical" and "Mindful") who despite similar sociodemographic profile differed significantly in their buying behaviour and attitudes towards sustainable products, labels and producers. These results are in line with current observations in consumer segmentation regarding sustainable food choices $[10,39,40]$. Verain et al. identified four segments of consumers ('unsustainers', 'curtailers', 'product-oriented consumers', and 'sustainers') according to sustainable product choices and behaviour [37]. This confirms that even "green" consumers (who attach importance to sustainability) are still not homogeneous as they may differ in the frequency with which they perform sustainable behaviours.

According to Janßen et al. consumers have different associations and opinions with certain sustainability labels what determines their choices and WTP. Three identified consumer segments ('the price sensitives', 'the price conscious label discriminators' and the 'label choosers') assessed differently the credence attributes of labels related the same and other pillars of sustainability [10]. Furthermore, the results confirm that consumers weigh labels against other characteristics during the stage of product evaluation in their decision-making process [40,41]. Overall, our study illustrates that sustainability labels signal credence attributes to consumers. The two identified clusters vary in relation 
to the importance they attach to logos and reveal different preferences for sustainable labelled products when making food choices. That's why we called one group "Sceptical" and the other "Mindful".

As stated by some authors the familiarity with food labels (i.e. knowledge, awareness of logos and names) is a basic prerequisite of use them in consumer decision making [13,42-45]. Nevertheless, it is worth mentioning that the familiarity level of certificates among consumers does not translate directly into the choice of certified products. First of all, consumers should at least notice the label on the food packaging and make some effort to understand what it means. Then consumers process the message in a central (receiver is motivated and able to process the message) or peripheral way (receiver is not motivated or not able to process it for example because of a lack of knowledge) that allows to form an attitude towards the label and use it in their decision-making process when shopping [43]. However, in contrast with the Ajzen and Fishbein theory of reasoned action [46], the positive attitudes towards buying sustainable food products are also not necessarily followed by positive buying intentions $[13,15,47]$.

Study of Peschel et al. confirmed that consumers have to put effort into understanding the labels and using this in the trade-offs of various product attributes (such as price, functional etc.) what finally determines their choice [44]. Similar findings were revealed in work conducted by Grunert et al. Sustainability labels use is influenced by awareness of their graphic symbols and/or names and their ability to communicate of their meaning [13]. Hanss and Böhm reported that consumers need to be familiar with, and have trust in sustainability labels before they will purchase these products [48]. According to all the above-mentioned authors, familiarity level is just one of the factors affecting the use of sustainability labels.

The results of our study indicated a relatively high level of familiarity of the Euro-leaf, PGI and Fair Trade labels among Polish consumers. This was not followed by consumers' preferences and choice of food products with particular sustainability label. Although EU organic farming logo has the highest level of recognition, consumers did not choose it most often during the behavioural experiment. This suggests that consumer level of familiarity does not determine directly sustainability labels use. Whereas it was also found that the positive consumers attitude towards labels influenced the choice of labelled food during shopping. "Mindful" consumers (Cluster 2) were more likely to choose products with a sustainability logo than "Sceptical" individuals (Cluster 1) and accepted higher prices compared to the products without any logo. On the other hand, when the labels are unknown and/or their meaning is not clear, even consumers with positive attitudes towards sustainability labels will not use them as guidance when shopping for food. During the behavioural experiment a relatively large part of consumers from Cluster 2 (about one quarter, depending on product category) didn't decide to buy a labelled product even when its price was the same as its non-labelled alternatives.

Existing literature on willingness to pay for food products affiliated with sustainability labels indicates that there is a highly price inelastic demand for them [10,44]. Large groups of consumers show preferences towards environmentally friendly products (with organic farming, animal welfare, carbon footprint, food miles, local production, geographical indications and traditional specialties, Fair Trade and etc. logos) but only if their prices are low or at least the same as that of conventional items [49-51]. In our study the share of consumers who would like to buy sustainability labelled products at the price of conventional food ranged from 50 to $80 \%$ and was greatly dependent on the type of food product. Non-perishable food items (rice and beans) were chosen more frequently than fresh foods (apples, bananas). Additionally, "Mindful" consumers, who attached higher importance to sustainability labels, declared a willingness to buy them more often than the "Sceptical" group. Nevertheless, as soon as the price of that item was raised a smaller number of consumers remained willing to buy and pay extra for the sustainable labelled products. In general, price was recognized as the major barrier to purchase sustainability labelled food [21]. Customers in their purchasing decisions compared it with price that is justified by the "true" value of the product what may be indicators of consumers' demand for that product [52]. Thus, according to Nielsen's research (on over 30 thousand consumers in 60 countries in 2015), 66\% of consumers was willing to pay more for sustainable goods 
and services [53]. A GfK survey (25,000 US consumers in 2017), found that $56 \%$ claimed they are willing to pay extra for "green" products [54]. On the other hand, food market studies reveal that the proportion of consumers ready to pay a premium for environmentally friendly products is much lower and the average reported WTP appears to be approximately 30\% [21]. A large number of studies focused on organic food [11,26,55-58], geographical indications and traditional specialties [5,59-62], and Fair Trade labelled products [25,63-65]. These studies reveal that consumers want to pay more but WTP differ according to products, label and between countries. Our results also indicate the importance of price in shaping the WTP. In fact, the average reported WTP for labelled products was less than $20 \%$ and consumers differed in terms of their level of willingness to choose higher-priced sustainable labelled products. In our study "Sceptical" consumers (who generally do not recognize benefits of purchasing them) were very price sensitive (more than $50 \%$ switched product when its price increase was higher than 20\%). The "Mindful" segment also reacted to price changes, but to a lesser extent.

\section{Conclusions}

Our study shows that urban consumers in Poland vary in regard to the value they attach to sustainability labelled food products, however $1 / 3$ of them is more "mindful" and has higher WTB and WTP for such foods.

We conclude that sustainability labels influence consumer buying behaviour in spite of the fact that consumers perceive the benefits of buying them differently. Consumer organisations, government agencies and food industry organisations should take more action to raise awareness of the idea of food certification and the importance of individual certificates to promote the choice of certified food products more intensively.

Finally, our findings confirm that Polish urban consumers are very price sensitive in terms of buying products with sustainability logos. Therefore, the value added of sustainable products should be communicated very clearly by producers in order to enable consumers to make informed choices in line with sustainable food consumption recommendations. There is a need to tackle the crucial role of price that can inhibit the growth of demand among consumers. Information campaigns in this area should draw attention to making consumers aware that prices of certified products must be higher than those of conventional products, and that surplus prices bring particular benefits to them. Otherwise a large consumer group is excluded from sustainable consumption.

Author Contributions: Conceptualization, J.K., K.R. and E.H.; methodology, J.K. and K.R.; data extraction and synthesis, J.K., Writing-Original draft preparation, J.K., Writing-Review and editing, A.S., E.H., K.R. and J.K.; supervision K.R. and H.G.-W. All authors read and approved the final manuscript.

Funding: The research was financed by the Polish Ministry of Science and Higher Education within funds of the Faculty of Human Nutrition and Consumer Sciences, Warsaw University of Life Sciences (WULS-SGGW) for scientific research. The funder had no role in the design, analysis or writing of this article.

Acknowledgments: Authors are grateful to ARC Rynek i Opinia market research agency for their technical support during behavioural choice experiment (CE).

Conflicts of Interest: The authors declare no conflict of interest.

\section{References}

1. Verain, M.C.D.; Bartels, J.; Dagevos, H.; Sijtsema, S.J.; Onwezen, M.C.; Antonides, G. Segments of Sustainable Food Consumers: A Literature Review. Int. J. Consum. Stud. 2012, 36, 123-132. [CrossRef]

2. Sustain: The Alliance for Better Food and Farming. Eat Well and Save the Planet! A Guide for Consumers on How to Eat Greener, Healthier and More Ethical Food. Available online: https://www.sustainweb.org/ pdf/SFG_Consumers_1pp.pdf (accessed on 15 July 2019).

3. Rejman, K.; Kaczorowska, J.; Halicka, E.; Laskowski, W. Do Europeans Consider Sustainability When Making Food Choices? A Survey of Polish City-Dwellers. Public Health Nutr. 2019, 22, 1330-1339. [CrossRef] [PubMed] 
4. Engels, S.V.; Hansmann, R.; Scholz, R.W. Toward a Sustainability Label for Food Products: An Analysis of Experts' and Consumers' Acceptance. Ecol. Food Nutr. 2010, 49, 30-60. [CrossRef] [PubMed]

5. Aprile, M.C.; Caputo, V.; Nayga, R.M. Consumers' Valuation of Food Quality Labels: The Case of the European Geographic Indication and Organic Farming Labels. Int. J. Consum. Stud. 2012, 36, 158-165. [CrossRef]

6. Ipsos; London Economics Consortium. Consumer Market Study on the Functioning of Voluntary Food Labelling Schemes for Consumers in the European Union EAHC/FWC/2012 86 04; European Commission: Brussels, Belgium; Executive Agency for Health and Consumers (EAHC): London, UK, 2013.

7. Official Journal of the European Union. Commission Communication-EU best practice guidelines for voluntary certification schemes for agricultural products and foodstuffs 2010/C 341/04. Available online: https://eur-lex.europa.eu/LexUriServ/LexUriServ.do?uri=OJ:C:2010:341:0005:0011:en:PDF (accessed on 22 October 2019).

8. Halicka, E. Development of Food Quality Assurance and Certification Schemes. In Challenges and Perspectives for the European Food Market; Kowrygo, B., Rejman, K., Eds.; Warsaw University of Life Sciences Press: Warsaw, Poland, 2008; pp. 107-116.

9. Rodrigues, D.B.; de Dalmarco, D.A.S.; Aoqui, C.; de Marinho, B.L. The Meaning of the Organic Certification Label for the Consumer: A Cluster Analysis. REGE Rev. Gestão 2016, 23, 316-325. [CrossRef]

10. Janßen, D.; Langen, N. The Bunch of Sustainability Labels-Do Consumers Differentiate? J. Clean. Prod. 2017, 143, 1233-1245. [CrossRef]

11. Liu, C.C.; Chen, C.W.; Chen, H.S. Measuring Consumer Preferences and Willingness to Pay for Coffee Certification Labels in Taiwan. Sustainability 2019, 11, 1297. [CrossRef]

12. Areté Research \& Consulting in Economics. Inventory of Certification Schemes for Agricultural Products and Foodstuffs Marketed in the EU Member States. Available online: https://ec.europa.eu/agriculture/ sites/agriculture/files/quality/certification/inventory/inventory-data-aggregations_en.pdf (accessed on 23 September 2019).

13. Grunert, K.G.; Hieke, S.; Wills, J. Sustainability Labels on Food Products: Consumer Motivation, Understanding and Use. Food Policy 2014, 44, 177-189. [CrossRef]

14. Ecolabel Index Pro. Ecolabel Index. Who's Deciding What's Green? Available online: http://www. ecolabelindex.com/ (accessed on 13 August 2019).

15. Vermeir, I.; Verbeke, W. Sustainable Food Consumption: Exploring the Consumer 'Attitude-Behavioral Intention' Gap. J. Agric. Environ. Ethics 2006, 19, 169-194. [CrossRef]

16. Ling, C.Y. Consumers' Purchase Intention of Green Products: An Investigation of the Drivers and Moderating Variable. Elixir Mark. Manag. 2013, 57A, 14503-14509.

17. O'Kane, G. What Is the Real Cost of Our Food? Implications for the Environment, Society and Public Health Nutrition. Public Health Nutr. 2012, 15, 268-276. [CrossRef] [PubMed]

18. Li, X.; Jensen, K.L.; Clark, C.D.; Lambert, D.M. Consumer Willingness to Pay for Beef Grown Using Climate Friendly Production Practices. Food Policy 2016, 64, 93-106. [CrossRef]

19. van Herpen, E.; Fischer, A.R.H.; van Trijp, H.C.M. How to Position 'mildly Sustainable' Products: The Joint Impact of Assortment Display and Price Setting. Food Qual. Prefer. 2015, 46, 26-32. [CrossRef]

20. Marian, L.; Chrysochou, P.; Krystallis, A.; Thøgersen, J. The Role of Price as a Product Attribute in the Organic Food Context: An Exploration Based on Actual Purchase Data. Food Qual. Prefer. 2014, 37, 52-60. [CrossRef]

21. Aschemann-Witzel, J.; Zielke, S. Can't Buy Me Green? A Review of Consumer Perceptions of and Behavior Toward the Price of Organic Food. J. Consum. Aff. 2017, 51, 211-251. [CrossRef]

22. Avitia, J.; Costa-Font, M.; Gil, J.M.; Lusk, J.L. Relative Importance of Price in Forming Individuals' Decisions toward Sustainable Food: A Calibrated Auction-Conjoint Experiment. Food Qual. Prefer. 2015, 41, 1-11. [CrossRef]

23. Ozimek, I.; Zakowska-Biemans, S. Determinants of Polish Consumers' Food Choices and Their Implication for the National Food Industry. Br. Food J. 2011, 113, 138-154. [CrossRef]

24. Combris, P.; Bazoche, P.; Giraud-Héraud, E.; Issanchou, S. Food Choices: What Do We Learn from Combining Sensory and Economic Experiments? Food Qual. Prefer. 2009, 20, 550-557. [CrossRef]

25. Vecchio, R.; Annunziata, A. Willingness-to-Pay for Sustainability-Labelled Chocolate: An Experimental Auction Approach. J. Clean. Prod. 2015, 86, 335-342. [CrossRef] 
26. Anastasiou, C.N.; Keramitsoglou, K.M.; Kalogeras, N.; Tsagkaraki, M.I.; Kalatzi, I.; Tsagarakis, K.P. Can the 'Euro-Leaf' Logo Affect Consumers' Willingness-to-Buy and Willingness-to-Pay for Organic Food and Attract Consumers' Preferences? An Empirical Study in Greece. Sustainability 2017, 9, 1450. [CrossRef]

27. Statistics Poland (GUS). Statistical Yearbook of the Regions-Poland 2017; Statistics Poland (GUS): Warsaw, Poland, 2018.

28. Grunert, K.G.; Brunso, K.; Bisp, S. Food-Related Life Style. Development of a Cross-Culturally Valid Instrument for Market Surveillance. MAPP Work. Pap. 1993, 12,1-44.

29. Balon, U.; Dziadkowiec, J.; Sikora, T. Rzetelność Narzędzia FRL (Food Related Lifestyles) w Polskim Środowisku Kulturowym. Żywność Nauka Technologia Jakość/Food. Sci. Technol. Qual. 2015, 22, 182-196. [CrossRef]

30. Breidert, C.; Hahsler, M.; Reutterer, T. A Review of Methods for Measuring Willingness-to-Pay. Innov. Mark. 2006, 2, 8-32.

31. Wakeling, I.N.; Buck, D. Balanced Incomplete Block Designs Useful for Consumer Experimentation. Food Qual. Prefer. 2001, 12, 265-268. [CrossRef]

32. Dubes, R.; Jain, A.K. Clustering Methodologies in Exploratory Data Analysis. Adv. Comput. 1980, 19, 113-228. [CrossRef]

33. TNS Opinion \& Social. Special Eurobarometer 473 Europeans, Agriculture and the CAP. Survey Requested by the European Commission; Directorate-General for Communication: Brussels, Belgium, 2018.

34. Aertsens, J.; Verbeke, W.; Mondelaers, K.; van Huylenbroeck, G. Personal Determinants of Organic Food Consumption: A Review. Br. Food J. 2009, 111, 1140-1167. [CrossRef]

35. Van Der Zanden, L.D.T.; Van Kleef, E.; De Wijk, R.A.; Van Trijp, H.C.M. Understanding Heterogeneity among Elderly Consumers: An Evaluation of Segmentation Approaches in the Functional Food Market. Nutr. Res. Rev. 2014, 27, 159-171. [CrossRef]

36. Onwezen, M.C.; Reinders, M.J.; van der Lans, I.A.; Sijtsema, S.J.; Jasiulewicz, A.; Dolors Guardia, M.; Guerrero, L. A Cross-National Consumer Segmentation Based on Food Benefits: The Link with Consumption Situations and Food Perceptions. Food Qual. Prefer. 2012, 24, 276-286. [CrossRef]

37. Verain, M.C.D.; Dagevos, H.; Antonides, G. Sustainable Food Consumption. Product Choice or Curtailment? Appetite 2015, 91, 375-384. [CrossRef]

38. Verain, M.C.D.; Sijtsema, S.J.; Dagevos, H.; Antonides, G. Attribute Segmentation and Communication Effects on Healthy and Sustainable Consumer Diet Intentions. Sustainability 2017, 9, 743. [CrossRef]

39. Verain, M.C.D.; Sijtsema, S.J.; Antonides, G. Consumer Segmentation Based on Food-Category Attribute Importance: The Relation with Healthiness and Sustainability Perceptions. Food Qual. Prefer. 2016, 48, 99-106. [CrossRef]

40. Van Loo, E.J.; Caputo, V.; Nayga, R.M.; Seo, H.S.; Zhang, B.; Verbeke, W. Sustainability Labels on Coffee: Consumer Preferences, Willingness-to-Pay and Visual Attention to Attributes. Ecol. Econ. 2015, 118, 215-225. [CrossRef]

41. Verbeke, W.; Ward, R.W. Consumer Interest in Information Cues Denoting Quality, Traceability and Origin: An Application of Ordered Probit Models to Beef Labels. Food Qual. Prefer. 2006, 17, 453-467. [CrossRef]

42. Annunziata, A.; Mariani, A.; Vecchio, R. Effectiveness of Sustainability Labels in Guiding Food Choices: Analysis of Visibility and Understanding among Young Adults. Sustain. Prod. Consum. 2019, 17, 108-115. [CrossRef]

43. Grunert, K.G. Sustainability in the Food Sector: A Consumer Behaviour Perspective. Int. J. Food Syst. Dyn. 2011, 2, 207-218.

44. Peschel, A.O.; Grebitus, C.; Steiner, B.; Veeman, M. How Does Consumer Knowledge Affect Environmentally Sustainable Choices? Evidence from a Cross-Country Latent Class Analysis of Food Labels. Appetite 2016, 106, 78-91. [CrossRef]

45. Thøgersen, J.; Haugaard, P.; Olesen, A. Consumer Responses to Ecolabels. Eur. J. Mark. 2010, 44, $1787-1810$. [CrossRef]

46. Ajzen, I. The Theory of Planned Behavior. Organ. Behav. Hum. Decis. Process. 1991, 50, 179-211. [CrossRef]

47. Shepherd, R. Social Determinants of Food Choice. Proc. Nutr. Soc. 1999, 58, 807-812. [CrossRef]

48. Hanss, D.; Böhm, G. Sustainability Seen from the Perspective of Consumers. Int. J. Consum. Stud. 2012, 36, 678-687. [CrossRef]

49. Feldmann, C.; Hamm, U. Consumers' Perceptions and Preferences for Local Food: A Review. Food Qual. Prefer. 2015, 40, 152-164. [CrossRef] 
50. Van Loo, E.J.; Caputo, V.; Nayga, R.M.; Verbeke, W. Consumers' Valuation of Sustainability Labels on Meat. Food Policy 2014, 49, 137-150. [CrossRef]

51. Biswas, A.; Roy, M. Green Products: An Exploratory Study on the Consumer Behaviour in Emerging Economies of the East. J. Clean. Prod. 2015, 87, 463-468. [CrossRef]

52. Krystallis, A.; Chryssohoidis, G. Consumers' Willingness to Pay for Organic Food: Factors That Affect It and Variation per Organic Product Type. Br. Food J. 2005, 107, 320-343. [CrossRef]

53. Nielsen. The Sustainability Imperative New Insights on Consumer Expectations; Nielsen Company: New York, NY, USA, 2015.

54. GfK United States. Press Release: In US, Willingness to Pay More for Environment-Friendly Products Grows. Available online: https://www.gfk.com/en-us/insights/press-release/in-us-willingness-to-pay-morefor-environment-friendly-products-grows/ (accessed on 23 November 2019).

55. Díaz, F.J.M.; Pleite, F.M.C.; Paz, J.M.M.; García, P.G. Consumer Knowledge, Consumption, and Willingness to Pay for Organic Tomatoes. Br. Food J. 2012, 114, 318-334. [CrossRef]

56. Van Loo, E.J.; Caputo, V.; Nayga, R.M.; Meullenet, J.F.; Ricke, S.C. Consumers' Willingness to Pay for Organic Chicken Breast: Evidence from Choice Experiment. Food Qual. Prefer. 2011, 22, 603-613. [CrossRef]

57. Janssen, M.; Hamm, U. Product Labelling in the Market for Organic Food: Consumer Preferences and Willingness-to-Pay for Different Organic Certification Logos. Food Qual. Prefer. 2012, 25, 9-22. [CrossRef]

58. McFadden, J.R.; Huffman, W.E. Willingness-to-Pay for Natural, Organic, and Conventional Foods: The Effects of Information and Meaningful Labels. Food Policy 2017, 68, 214-232. [CrossRef]

59. Garavaglia, C.; Mariani, P. How Much Do Consumers Value Protected Designation of Origin Certifications? Estimates of Willingness to Pay for PDO Dry-Cured Ham in Italy. Agribusiness 2017, 33, 403-423. [CrossRef]

60. Deselnicu, O.C.; Costanigro, M.; Souza-Monteiro, D.M.; Thilmany McFadden, D. A Meta-Analysis of Geographical Indication Food Valuation Studies: What Drives the Premium for Origin-Based Labels? J. Agric. Resour. Econ. 2013, 38, 204-219.

61. de-Magistris, T.; Gracia, A. Consumers' Willingness to Pay for Light, Organic and PDO Cheese: An Experimental Auction Approach. Br. Food J. 2016, 118, 560-571. [CrossRef]

62. Erraach, Y.; Sayadi, S.; Gómez, A.C.; Parra-López, C. Consumer-Stated Preferences towards Protected Designation of Origin (PDO) Labels in a Traditional Olive-Oil-Producing Country: The Case of Spain. New Medit 2014, 13, 11-19.

63. Mahé, T. Are Stated Preferences Confirmed by Purchasing Behaviours? The Case of Fair Trade-Certified Bananas in Switzerland. J. Bus. Ethics 2010, 92, 301-315. [CrossRef]

64. Yang, S.-H.; Hu, W.; Mupandawana, M.; Liu, Y. Consumer Willingness to Pay for Fair Trade Coffee: A Chinese Case Study. J. Agric. Appl. Econ. 2012, 44, 21-34. [CrossRef]

65. Maaya, L.; Meulders, M.; Surmont, N.; Vandebroek, M. Effect of Environmental and Altruistic Attitudes on Willingness-to-Pay for Organic and Fair Trade Coffee in Flanders. Sustainability 2018, 10, 4496. [CrossRef] 